\title{
CHARACTERIZATION OF THE PREDOMINANT WIND SPEED AND DIRECTION IN SANTA CATARINA, BRAZIL
}

\author{
WAHRLICH, Júlia - julia.wahrlich@gmail.com \\ Universidade do Estado de Santa Catarina / UDESC \\ SILVA, Flávia Arcari da - flarcari@hotmail.com \\ Universidade do Estado de Santa Catarina / UDESC
CAMPOS, Claudia Guimarães Camargo - claudia.campos@udesc.br
Universidade do Estado de Santa Catarina / UDESC \\ RODRIGUES, Maria Laura Guimarães - mlauragr@gmail.com \\ Empresa de Pesquisa Agropecuária e Extensão Rural de Santa Catarina / \\ EPAGRI

\begin{abstract}
MEDEIROS, Jéssica - jessicaisraelem@hotmail.com Universidade do Estado de Santa Catarina / UDESC
\end{abstract}

\begin{abstract}
The state of Santa Catarina presents significant spatial variations in its climate, with different regional peculiarities. Wind is considered an important meteorological variable, but it is not sufficiently studied and there is a shortage of information on this subject in the region of Santa Catarina. Thus, the objective of this article was to analyze the behavior of the winds in five regions of the state, with different aspects: altitude, topography and climatology patterns. For that, daily data from National Institute of Meteorology of direction and speed of the winds were used from 1974 to 2016. The conventional meteorological stations used were: Chapecó, Campos Novos, Lages, Indaial and Florianópolis. The data were submitted through consistence analysis, monthly descriptive statistics of the velocity were obtained, the predominant direction was characterized through frequency analysis and a conceptual model of prevailing winds in the state was created. Regarding wind speed, Florianópolis and Campos Novos registered the highest speeds during the whole year. In the analysis of wind direction, the prevalence of South Atlantic subtropical anticyclone was observed in most of the year in Florianópolis (circulation from north), Lages and Campos Novos (from northeast). In Chapecó, the predominant east wind direction is associated with the low pressure system in the Paraguay region. For Indaial, the orography has a strong influence on the local circulation, favoring a southwest wind direction, by the formation of the mountain-valley breeze, which has as a forcing the air temperature differences between the valley and the mountain in the night period.
\end{abstract}

KEYWORDS: Wind climatology; Synoptic circulation; Local circulation; Santa Catarina

CARACTERIZAÇÃO DA VELOCIDADE E DIREÇÃO PREDOMINANTE DOS VENTOS EM SANTA CATARINA, BRASIL

RESUMO: Apesar do estado de Santa Catarina possuir pouca variação na latitude, apresenta variações espaciais significativas no seu clima, como verificado neste estudo. O vento é considerado uma importante variável meteorológica, porém não é suficientemente estudado e existe uma escassez de informações sobre esse assunto na região de Santa Catarina. Sendo assim, o objetivo deste artigo foi analisar o comportamento dos ventos em regiões do estado, com diferentes aspectos: altitude, topografia e padrões climáticos. Para tanto, foram utilizados dados diários no Instituto Nacional de Meteorologia (INMET) da direção e velocidade dos ventos no período de 1974 a 2016. As estações meteorológicas convencionais utilizadas foram: Chapecó, Campos Novos, Lages, Indaial e Florianópolis. Após consistidos, os dados diários de vento foram 
submetidos a analises de estatísticas descritivas mensais da velocidade do vento e análise de frequência das direções predominantes, assim como foi determinado um modelo conceitual dos ventos predominantes no estado. Com relação à velocidade do vento, Florianópolis e Campos Novos registraram as maiores velocidades durante todo o ano. $\mathrm{Na}$ análise da direção do vento, o predomínio do anticiclone subtropical do Atlântico Sul (ASAS) foi observado na maior parte do ano em Florianópolis (circulação de Norte), Lages e Campos Novos (de Nordeste). Em Chapecó, a direção do vento predominante de Leste está associada ao sistema de baixa pressão na região do Paraguai. Para Indaial, a orografia tem forte influência na circulação local, favorecendo uma direção de vento de Sudoeste, pela formação da brisa vale-montanha, a qual tem como forçante as diferenças de temperatura do ar entre o vale e a serra, no período noturno.

PALAVRAS-CHAVE: Climatologia de vento; Circulação sinótica; Circulação local; Santa Catarina.

\section{INTRODUCTION}

Winds may be understood as the movement parcels of air in relation to the Earth surface, being able to occur vertically or horizontally and varying with direction and velocity (AYOADE, 1996). Its formation is due to the pressure variation between different regions, where the air mass goes from high pressure points to low pressure points, resulting in the air mass movement and thus characterizing the wind (MARIM et al., 2008). According to the same authors, once the air mass movement is formed, its displacement suffers influence of the Coriolis Effect, always perpendicular to the movement direction, the centripetal force and the friction effect, active in layers close to surface.

Located in the southeast portion of South America and bathed by the South Atlantic Ocean, the State of Santa Catarina presents a circulation of winds associated to high and low pressure atmospheric systems characteristics of the South Brazil (PEZZA, 2003; RODRIGUES et al., 2004; GRIMM, 2009; CARDOSO et al., 2012). The South Atlantic Subtropical Anticyclone, semi-permanent highpressure system (Figure 1), dominates the climate in most of Brazil during the year, favoring the wind flow in northeast/east (coming from the sea towards the continent) in the south of the country (GRIMM, 2009). This circulation pattern is broken by transient atmospheric systems, typical of mid-latitudes, that cause changes in the climate of south of Brazil (SATYAMURTY et al., 1998; CAVALCANTI and KOUSKY, 2009).

Among these systems, the cold fronts stand out (Figure 1), with a weekly mid frequency in Santa Catarina and southwest-northeast displacement, favoring a change in the wind direction (RODRIGUES et al., 2004), which turn from north quadrant to south quadrant. The migratory anticyclones (high pressures) that advance from Argentina to the South Brazil, in the rearguard of cold fronts (Figure 1), favor southwest winds in the coast of Santa Catarina in the winter or southeast in the summer. 


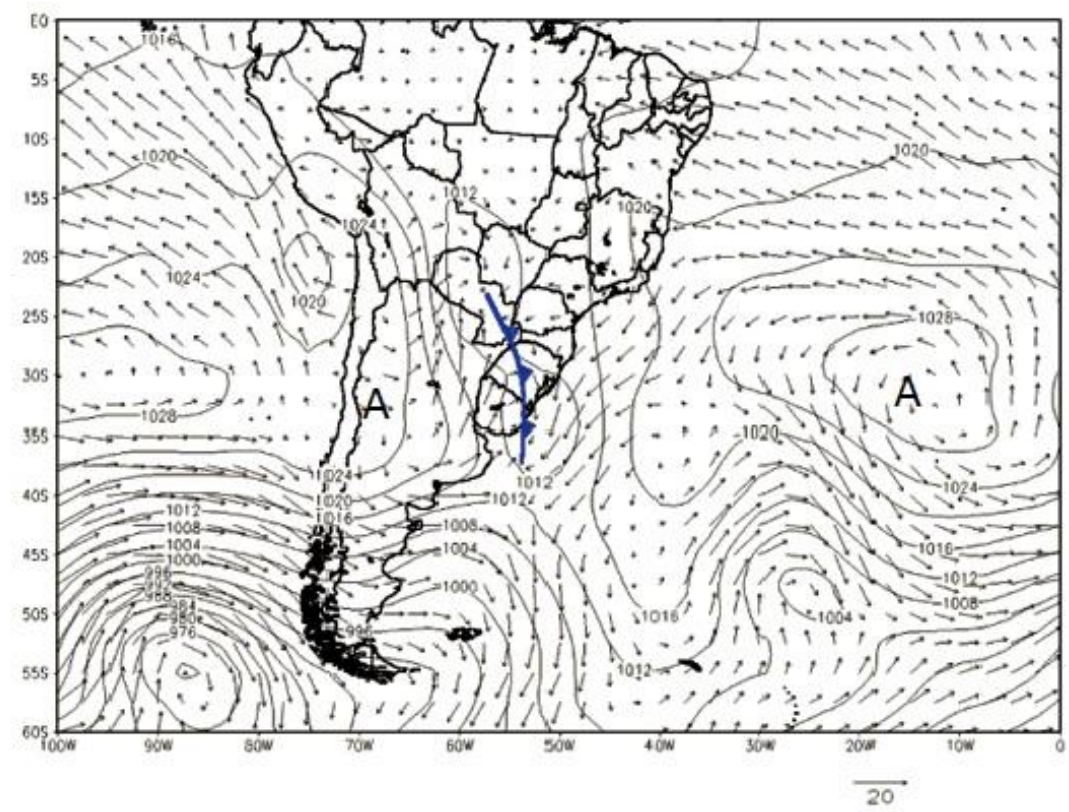

Figure 1 - Pressure field at the sea mid-level $(\mathrm{hPa})$ and wind in $10 \mathrm{~m}(\mathrm{~m} / \mathrm{s})$, indicating centers of high pressure $(A)$ in South Atlantic and Argentina, and cold front in South Brazil. Source: Rodrigues et al., 2004.

Cyclones (low pressures) that form or intensify in Paraguay (SELUCHI and SAULO, 2012) also move towards Santa Catarina, in every station of the year (PEREIRA, 2013), altering the wind configuration while following the trajectory from the west in direction to the south coast of Brazil. When they reach the coast, these cyclones intensify, especially in the months between May and September (GAN and RAO, 1991), resulting in strong south winds from the coastal areas and the south of the state (CARDOSO et al., 2012). The anticyclones and cyclones favor a persistent wind circulation, during hours or days, contributing to the average circulation pattern in the south of Brazil. According to these high and low atmospheric pressure systems intensity, it is verified a major or minor wind intensity in different regions of Santa Catarina. According to Bitencourt et al. (2011), the wind intensity in the south coast of Brazil, associated with extratropical cyclones on the sea, are influenced by the intensity of these systems and its distance to the coast.

The winds in the south of Brazil east region, from the action of extratropical cyclones or cold fronts, result in economic and social impacts, affecting fishing, port and tourist activities (RODRIGUES et al., 2004; CARDOSO et al., 2012).

In the south coast of Santa Catarina, in 2004, although cyclones are common in this region, the population was surprised by the magnitude of the winds during the hurricane Catarina, cyclone that caused severe damage, lack of energy power, water and means of communication in the days following the event (LOPES and ESPÍNOLA, 2012; BITENCOURT and ROCHA, 2014). This, however, was a rare event, of the only recorded hurricane in the south Atlantic, which maximum wind register was of $146,7 \mathrm{~km} / \mathrm{h}$ in the south of Santa 
Catarina, highlighting the absence of measurements in that period (RODRIGUES et al., 2005).

The south region of Brazil is also exposed to strong winds by being a prone region to weather severe convective conditions (storm), due to its geographical location, such as other areas in the mid-latitudes of Latin America: Argentina northeast, Paraguay and Uruguay (NASCIMENTO and DOSWEL, 2006; ZIPSER et al., 2006; DURADOÑA et al., 2015). In the case of storms, the high winds are momentary, occurring in few minutes or seconds. The occurrence of storms, in Santa Catarina, is verifiable especially in the months of spring and summer, and the west has been the most affected region of state by gale (HERRMANN et al., 2007). To some storm events, in the south of Brazil, there were registered cases of tornado, while the strong winds reach extreme values with great power of destruction. An event devastated the west region of the state on the fall of 2015, classified as a tornado (HASSAN et al., 2017), that left several families without energy power by days, several constructions destroyed and had fatalities.

Winds of high intensity may be responsible for a series of damages to activities in general and hazards to the society. Santa Catarina economy is mainly driven by agriculture, farming of small and medium scale, textile, ceramic, metal-mechanical and electrical industries (ALVES et al., 2014). Agriculture, specially, is mainly dependent on climate conditions and therefore gale, storms and hail can severely affect production (NETO, 2014).

Although being an important weather variable, the wind is not intensively explored. The study of wind direction and velocity configures an important role as a source of data to different activities. The knowledge of the wind characteristics is crucial in activities such as agriculture, pesticides application, pollination and windbreak practices, to industry installation, in a way to avoid the plumes of pollution propagation towards the cities and in its use as source of renewable energies (MUNHOZ and GARCIA, 2008). Knowledge of the direction and intensity of the predominant wind in a region can contribute to the planning of lake, sea, tourist and sports activities, or urban and airport planning.

Therefore, it is essential, beyond characterizing the wind direction and average velocity, to study intense and extreme events. The extreme wind analysis is necessary to Civil Defense planning, seeking to minimize wind-borne disasters, by mapping regions prone to the occurrence of such events, to civil engineering, giving support to structural calculation and yet the electric power distribution network (GONÇALVES, 2007).

Extreme winds can be characterized according to how rare and intense they are, and regarding the impacts, they cause in the environment and economy (BENISTON and STEPHENSON, 2004). According to the Intergovernmental Panel on Climate Change (IPCC), "an extreme weather event would normally be as rare as or rarer than the 10th or 90th percentile", considering that an extreme event may vary from place to place (IPCC, 2007).

Giving due importance to the wind and considering the information needs on the regions of the state of Santa Catarina, this article aims to analyze the 
behavior of the winds in regions of the state with different aspects and characteristics.

As specific objectives, it was sought to verify the historical series of conventional stations of Chapecó, Campos Novos, Lages, Indaial and Florianópolis, assessing the changes in the wind behavior regarding its velocity and direction throughout the years.

\section{MATERIALS AND METHODS}

In this study, there were used daily wind direction and velocity data issued by the Brazilian National Meteorological Institute (INMET), from January 1974 until December 2016, with a total of 42 years, which is superior to the 30 years period recommended by the World Meteorological Organization (WMO) to the climatological normals.

The area of study is the Santa Catarina state, located at the south region of Brazil. The state has a population of over 7 million people and a human development index of 0,774 , which is one of the best indexes in Brazil. With an area of $95.737,954 \mathrm{~km}^{2}$, the state has one of the minor areas of the country (IBGE, 2018). Still, despite of having a small latitudinal distance, the state presents a complex relief, with coastal plains, mountain ranges, plateaus and depressions, and expressive spatial climate variations.

Therefore, there was decided to choose the weather stations with the larger historical series, which would represent the local characteristics of each region of the state, with stations at the west, mid-west, mountain region, coastal and the valley in north of the state. Moreover, these stations had an overall daily consistent data. The location and altitude of the conventional weather stations studied are shown in Table 1.

According to the classification proposed by Köppen, the climate of the state of Santa Catarina is classified as temperate, constantly humid, without dry season, type $\mathrm{Cfa}$ (hot summers) and $\mathrm{Cfb}$ (mountainous region, with mild summers). The average annual air temperature varies between $11^{\circ} \mathrm{C}$ and $21^{\circ} \mathrm{C}$, with maximum months in January and February and minimums in June. The mean annual precipitation corresponds to $1600 \mathrm{~mm}$ and average annual relative increase between $71 \%$ and $83 \%$ (PANDOLFO et al., 2002).

The weather stations chosen were (Figure 2): Chapecó, Campos Novos, Lages, Indaial and Florianópolis. According to the climate characteristics presented by Herrmann et al. (2007) and Grimm (2009), the west (Chapecó) is one of the main regions hit by storms with winds and hail, especially in spring, the rainiest quarter of the year in the region, presenting the highest annual total precipitation. Between west and south (Chapecó, Campos Novos and Lages), it is verified the major action of the polar air masses, which results in low temperatures in the months of fall-winter, season favourable to frost in these areas of the state. The coast (Florianópolis) is the region most hit by strong winds associated to the actions of extratropical cyclones, that are more intense close to the coast especially during the fall-winter months. In the summer months, the volume of rain increases significantly in the north of Santa Catarina, including the Itajaí valley, region known by historic floods. 

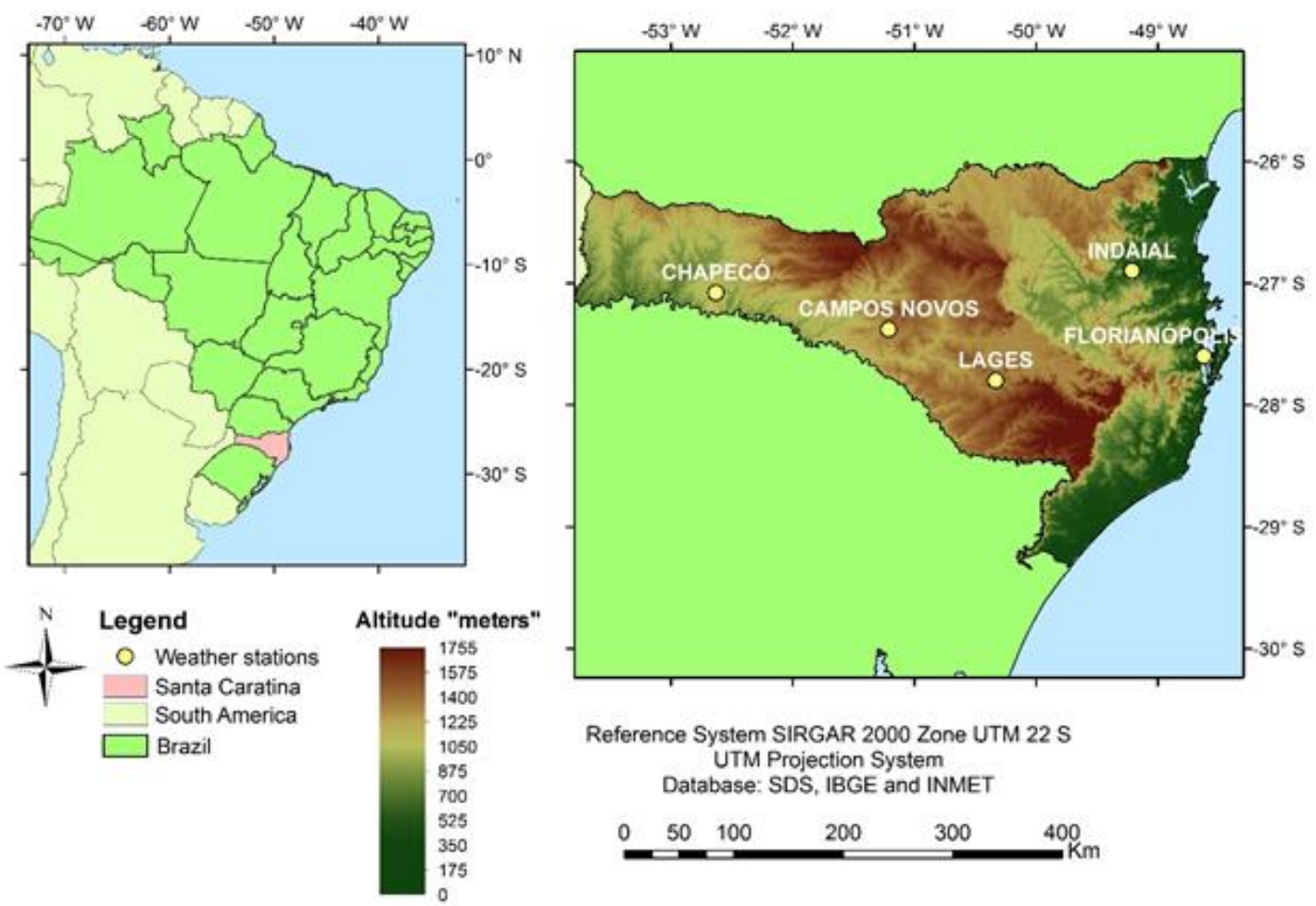

Figure 2 - Location of weather stations studied.

Table 1 - Conventional stations studied.

\begin{tabular}{c|ccc}
\hline Weather Stations & Latitude & Longitude & Altitude $(\mathbf{m})$ \\
\hline Chapecó & $-27.08^{\circ}$ & $-52.64^{\circ}$ & 687 \\
Campos Novos & $-27.38^{\circ}$ & $-51.22^{\circ}$ & 964 \\
Lages & $-27.80^{\circ}$ & $-50.34^{\circ}$ & 937 \\
Florianópolis & $-27.60^{\circ}$ & $-48.62^{\circ}$ & 1.84 \\
Indaial & $-26,9^{\circ}$ & $-49,22^{\circ}$ & 86.13 \\
\hline
\end{tabular}

Source: INMET, 2017.

The data collection made by INMET were through a universal anemograph, which continuously registers the direction (in degrees) with hourly measurement $(12 \mathrm{~h}, 18 \mathrm{~h}, 0 \mathrm{~h})$ of the wind velocity $(\mathrm{m} / \mathrm{s})$ measured daily and the total distance $(\mathrm{km})$ traveled by the wind. The universal anemograph is installed 2 meters above the soil surface.

For this reason, the data were submitted to the consistency analysis on the software Minitab 17.1.0 to verify the missing data and the outlier's. The missing wind data were not estimated due to the variability of the wind, both temporally and spatially, to avoid leading to errors in the results. It is 
noteworthy that the historical series were chosen for being very homogeneous and not presenting many flaws. The number of data analyzed was not the same to all the stations, since it was chosen to use only the consistent values of the five stations.

The Microsoft Excel software was used to work the data and obtain monthly descriptive statistics of the wind velocity to the studied period, as well as columns and radar graphs (which allowed the wind rose style of analysis). The descriptive statistic obtained were the measures of maximum, minimum, sum, central trend and position (mean, medium, mode), dispersion measures (standard error, standard deviation, sample variance, range) and measures of asymmetry (skewness) and kurtosis. The measures allowed to retake the data and verify their behavior. Subsequently, an analysis was performed with reference to the Beaufort wind-scale, according to the WMO Code Manual (2016) to characterize wind speed.

The predominant wind direction was characterized through frequency analysis of the registered observations during the studied period, to each station, using the equation (1), where $f(x)$ is the wind frequency occurrence in a determined direction, $\mathrm{n}$ is the number of occurrences of a determined direction and $\mathrm{N}$ is the total number of observations.

$$
f(x)=\frac{n}{N} x 100
$$

Together with all the data obtained, a conceptual model of prevailing winds in the state of Santa Catarina was created based on the configuration of the wind direction, main and secondary, respectively, in different stations, which can be understood from the atmospheric circulation generated in association with the synoptic systems that act in the SC state.

\section{RESULTS AND DISCUSSIONS}

The results of the five stations from 1974 until 2016 were compiled considering the average of velocity and directions.

\subsection{WIND VELOCITY}

The daily average velocities of 42 years were used to calculate the monthly averages of this period for each year, afterwards calculating the average of these values, obtaining one wind average velocity for each month. In Table 3 it is possible to observe the descriptive statistics of the five stations velocities averages. In order to obtain a better visualization, the results were compiled in the graphic presented in Figure 3, with the wind velocities monthly averages of each municipality, enabling a comparison throughout the year. 


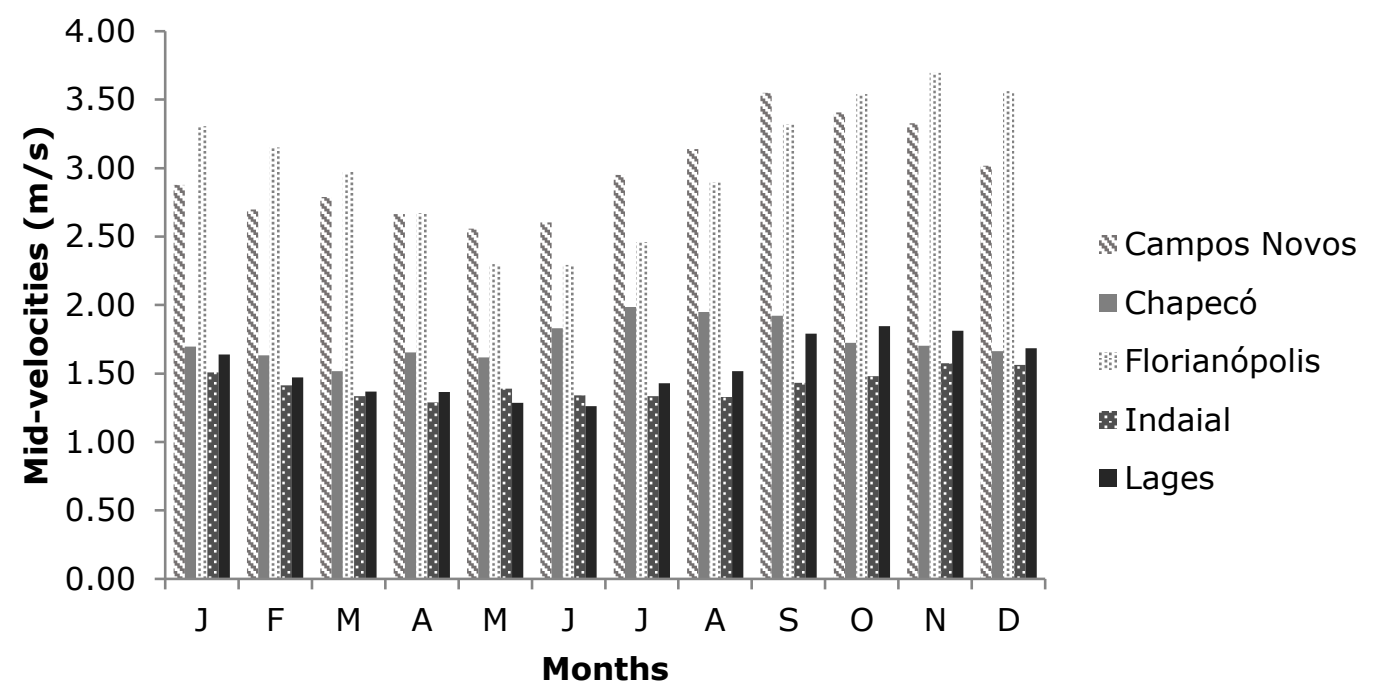

Figure 3 - Wind averages velocities $(\mathrm{m} / \mathrm{s})$ of the five stations.

Table 3 - Monthly descriptive statistics of the 42 years analyzed.

\begin{tabular}{|c|c|c|c|c|c|c|c|c|c|}
\hline \multicolumn{2}{|c|}{ Campos Novos } & \multicolumn{2}{|l|}{ Chapecó } & \multicolumn{2}{|l|}{ Florianópolis } & \multicolumn{2}{|l|}{ Indaial } & \multicolumn{2}{|l|}{ Lages } \\
\hline Mean & 2,97 & Mean & 1,74 & Mean & 3,01 & Mean & 1,42 & Mean & 1,54 \\
\hline Standard error & 0,10 & Standard error & 0,04 & Standard error & 0,14 & Standard error & 0,03 & Standard error & 0,06 \\
\hline Median & 2,91 & Median & 1,70 & Median & 3,06 & Median & 1,40 & Median & 1,49 \\
\hline Standard deviation & 0,33 & Standard deviation & 0,15 & Standard deviation & 0,50 & Standard deviation & 0,10 & Standard deviation & 0,21 \\
\hline Sample variance & 0,11 & Sample variance & 0,02 & Sample variance & 0,25 & Sample variance & 0,01 & Sample variance & 0,04 \\
\hline Kurtosis & $-0,95$ & Kurtosis & $-0,85$ & Kurtosis & $-1,34$ & Kurtosis & $-1,12$ & Kurtosis & $-1,49$ \\
\hline Skewness & 0,52 & Skewness & 0,49 & Skewness & $-0,24$ & Skewness & 0,48 & Skewness & 0,23 \\
\hline Range & 0,99 & Range & 0,47 & Range & 1,40 & Range & 0,29 & Range & 0,58 \\
\hline Minimum & 2,56 & Minimum & 1,52 & Minimum & 2,29 & Minimum & 1,29 & Minimum & 1,26 \\
\hline Maximum & 3,55 & Maximum & 1,98 & Maximum & 3,70 & Maximum & 1,57 & Maximum & 1,85 \\
\hline Sum & 35,58 & Sum & 20,90 & Sum & 36,17 & Sum & 17,00 & Sum & 18,47 \\
\hline
\end{tabular}

The annual averages in Chapecó, Indaial and Lages, between 1,42 m/s and $1,74 \mathrm{~m} / \mathrm{s}$, represent almost half of the value obtained to Florianópolis and Campos Novos, of approximately $3 \mathrm{~m} / \mathrm{s}$ (Table 3). Analysing studies of wind velocity in other regions of the south-center of Brazil, there was found an annual average of $2 \mathrm{~m} / \mathrm{s}$ in Dourados/MS (SILVA and VIEIRA, 2016), in the interior of the continent, and monthly averages of $2,5 \mathrm{~m} / \mathrm{s}$ to $4 \mathrm{~m} / \mathrm{s}$ in cities of south Brazil, such as Pelotas/RS (SILVA et al., 1997) and Ponta Grossa/PR (LEITE et al., 2006).

It is possible to observe in Figure 3 that the station of Campos Novos, in mid-west region, and Florianópolis, in the coast, registered the highest wind velocities during the year. Florianópolis, in relation to Campos Novos, presented higher wind velocities from October to March, and lower, during the months of May, June, July and August, having similar results, both the stations, in April. These stations are also the ones that presented highest standard deviation between the minimum and maximum values of the historic series (Table 3 ). This variability happens among the different seasons of the year, as shown in Figure 3. 
To all the weather stations, with exception of Chapecó, there is an increase of the wind velocity in the spring months. Similar results were found by Rodrigues et al. (2016), when evaluating wind climatology in Florianópolis. According to the authors, the highest speeds occurred from September to December. The studies of Silva et al. (1997), Leite and Virgens Filho (2006) and Munhoz and Garcia (2008), to different localities between Rio Grande do Sul and São Paulo also found highest wind velocities in the spring months. During this time of the year and in the summer, the South Atlantic Subtropical Anticyclone moves to the east, with its center moving away from the continent, while its west edge, region of intense winds, dominates the south and southeast coast of Brazil (GRIMM, 2009), as the east part of these regions.

In Campos Novos, the high wind speed in relation to Lages may be associated with less influence of the barriers in its proximities. Comparing winds series in a mesoregion of the Santa Catarina Island (Florianópolis), Bitencourt et al. (2016) verified a velocity variability associated mainly to the elevations in the surrounding.

Chapecó, as well as Indaial, were the stations that showed the least variability of the wind averages velocities during the year (Table 3). Located in valley (Figure 2), Indaial was the weather station that showed the lowest average velocities in most of the months. The valley region is considered of little or non-interest to the exploitation of wind energy, while the region of Florianópolis is one of the major exploitations of Wind energy in the state (FEITOSA et al., 2003).

The monthly average velocities obtained to the five weather stations were compared with the Beaufort scale, as demonstrated in Table 4.

Table 4 - Velocities classification (m/s) from 1974 until 2016 according to the Beaufort scale.

\begin{tabular}{|c|c|c|c|c|c|}
\hline Months & Campos Novos & Chapecó & Florianópolis & Indaial & Lages \\
\hline J & Light breeze & Light breeze & Light breeze & Light air & Light breeze \\
\hline F & Light breeze & Light breeze & Light breeze & Light air & Light air \\
\hline M & Light breeze & Light air & Light breeze & Light air & Light air \\
\hline A & Light breeze & Light breeze & Light breeze & Light air & Light air \\
\hline M & Light breeze & Light breeze & Light breeze & Light air & Light air \\
\hline J & Light breeze & Light breeze & Light breeze & Light air & Light air \\
\hline J & Light breeze & Light breeze & Light breeze & Light air & Light air \\
\hline A & Light breeze & Light breeze & Light breeze & Light air & Light air \\
\hline S & Gentle breeze & Light breeze & Light breeze & Light air & Light breeze \\
\hline O & Gentle breeze & Light breeze & Gentle breeze & Light air & Light breeze \\
\hline N & Light breeze & Light breeze & Gentle breeze & Light air & Light breeze \\
\hline D & Light breeze & Light breeze & Gentle breeze & Light air & Light breeze \\
\hline
\end{tabular}


Seeking a better understanding, the modal of the classification and the month's frequency were obtained (Figure 4). The averages velocities of Indaial station (Figure 3) were classified as "light air" in $100 \%$ of the months (Figure 4 ), a situation in which it is possible to observe the wind direction by smoke plumes. The averages of Lages were also classified as "light air" in 58,33\% of the months, from February to August, while the remaining months (spring and summer) were classified as "light breeze", which stands for leaves rustle in the wind. The Chapecó Station had $91,67 \%$ of the months averages classified as "light breeze", having only march classified as "light air".

The monthly averages of Campos Novos were classified as "light breeze" in $83,33 \%$ of the observations, while the September and October (spring) were classified as "gentle breeze", which stands for the leaves and small twigs in constant motion. In Florianópolis station, which presented the highest monthly wind velocities averages (Figure 3), 75\% were classified as "light breeze", representing the months of January to September, whilst the three spring months were classified as "gentle breeze", in which, far from land results on large wavelets, crests begin to break and scattered whitecaps.

These results confirm the lowest variability among the monthly average velocities for Indaial and Chapecó stations, already verified in Figure 3. Furthermore, it confirms the significant increase in the wind velocity during the spring months for Lages, Campos Novos and Florianópolis stations, beyond the intense wind persistence registered in Campos Novos and Florianópolis throughout the whole year.

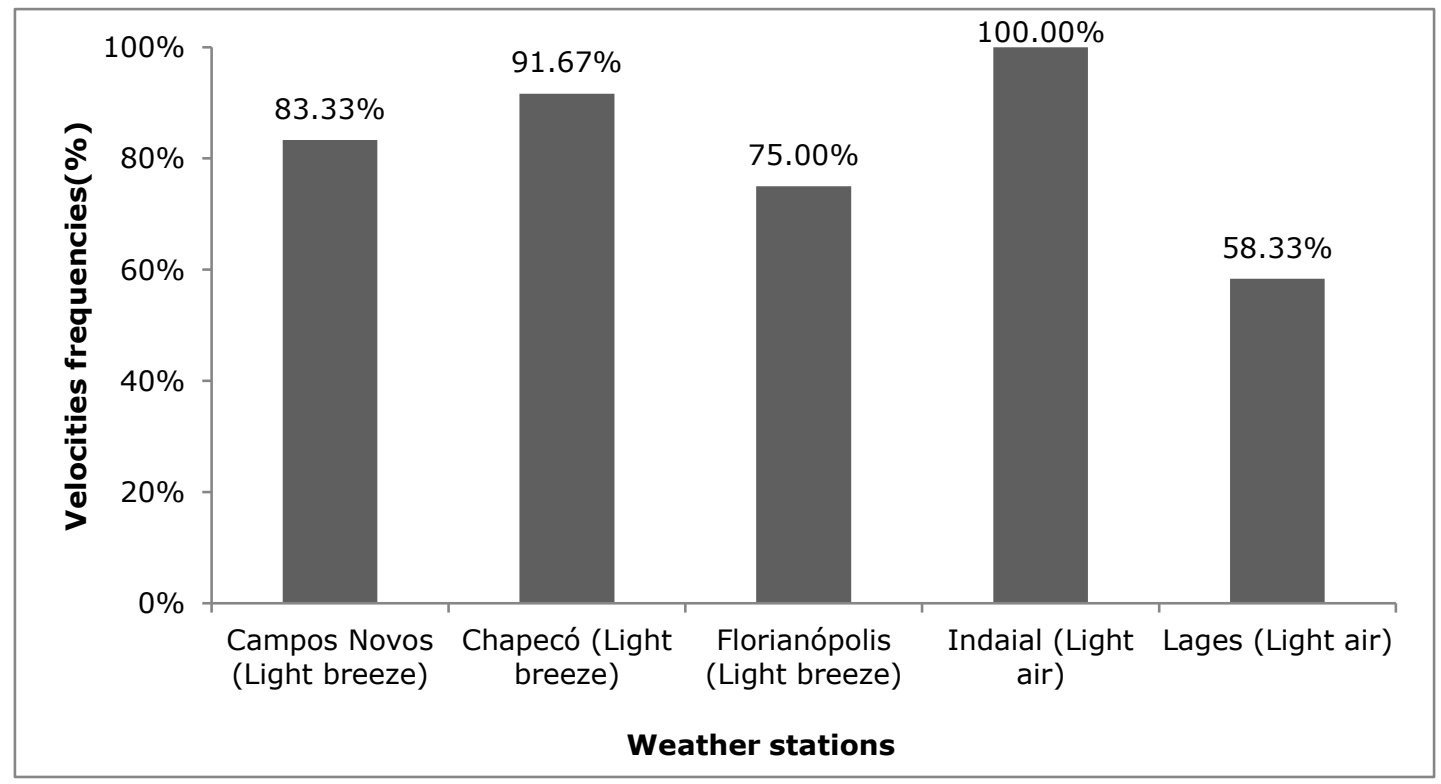

Figure 4 - Modal frequencies of each station.

It is important to emphasize that the previously discussed values refer to the monthly average of each station, in a way that the series extreme values were not in evidence. Therefore, the daily maximum averages of each month were analyzed to each station, and compared with the Beaufort scale, representing the days with highest persistence of wind high velocities. 
In the same way as observed to the monthly average velocities, the lowest maximum velocities were also registered in Indaial, Lages and Chapecó, while the highest ones were in Florianópolis and Campos Novos. The Lages Weather Station registered approximately $8 \mathrm{~m} / \mathrm{s}(28 \mathrm{~km} / \mathrm{h})$ maximum velocity value, while Indaial presented $10 \mathrm{~m} / \mathrm{s}(36 \mathrm{~km} / \mathrm{h})$, being these values classified as "strong breeze", in which large branches are in motion. Campos Novos had its maximum velocity of $17 \mathrm{~m} / \mathrm{s}(61,2 \mathrm{~km} / \mathrm{h})$, considered as "near gale", when there is the occurrence of whole trees in motion. The maximum speed registered in Florianópolis was $20 \mathrm{~m} / \mathrm{s}(72 \mathrm{~km} / \mathrm{h})$, classified as "gale", whose characteristics are ruptures of branches, generally impacting on traffic, electricity, housing and moderately high waves of greater length. To the days of maximum average velocity, there were verified the predominant atmospheric systems in Santa Catarina. In Florianópolis and Indaial Weather Stations, in the east of Santa Catarina, the maximum wind velocity occurred due to the extratropical cyclones action in the south coast of Brazil, being these typical systems of the region (GAN and RAO, 1991). In Campos Novos, the highest daily values of wind were in the day of the front passage and the previous day (north quadrant winds). The maximum wind in Lages was verified in this prefrontal same condition. The maximum register in Chapecó occurred in the year of 1984 that is between those of larger number of strong winds episodes in the west of Santa Catarina (HERRMANN et al., 2007) by front passages.

Thus, it is verified that the highest persistence of wind high velocities, in determined day, is associated to the action of atmospheric synoptic systems with strong pressure gradient. According to Rodrigues et al. (2004), intense winds of north quadrant are observed in Santa Catarina in the day that precedes the arrival of cold fronts from Rio Grande do Sul. In the present study, we see that in such conditions there are registered maximum daily winds velocities in the regions of Chapecó, Campos Novos and Lages, from the west in direction to the south of the state. In the east area of Santa Catarina (Florianópolis and Indaial), the maximum daily wind velocities are consequence of extratropical cyclones, that favors a strong pressure gradient in the coast, as analyzed by Bitencourt et al. (2011).

\subsection{WIND DIRECTION}

The most frequent wind directions are showed in Figure 5, organized as to represent the wind rose. Applying the q-square test in studies of wind frequency, Silva et al. (1997) identified that the observed frequencies of wind direction occur with a pattern characteristic from its locality.

The highest frequency of northeast and north quadrants, to most of the weather stations, is associated to the prevalence of South Atlantic subtropical anticyclone (high pressure with wind anti-clockwise and center at sea), which wind circulation dominates Brazilian coast during the year (GRIMM, 2009). It is possible to observe that Florianópolis, near the sea, showed the highest wind frequency in the north direction, and wind in northeast with lower frequency. According to Silveira et al. (2014), the metropolitan region of Florianópolis presented a slight variation in wind direction between the months. The north wind presence is observed in ten of twelve months of the year. The weather stations of Lages and Campos Novos showed the highest wind frequency in northeast direction. That is, as to the weather stations located more distant to 
the coast, the circulation due to the South Atlantic subtropical anticyclone acquires the northeast direction. Similar to the results here obtained, Leite and Virgens Filho (2006), in analysis of wind direction in Ponta Grossa, municipality of the State of Paraná, observed that northeast direction has the highest occurrence during the year, which was also verified by Silva et al. (1997) in the city of Pelotas, in Rio Grande do Sul. Both cities are located in the east-south of Brazil. The predominance of northeast wind was still noticed in Maringá/PR (GALVANI et al., 1999) and Dourado/MS (SILVA and VIEIRA, 2016), in the interior of the continent.

The Chapecó and Indaial weather stations showed high wind frequency in northeast direction too (Figure 5). The wind directions in Chapecó, in the west of Santa Catarina, were well distributed among northeast, east and southeast directions. In this station, southeast and east direction can be explained by the presence of troughs in the west of the south of Brazil, associated with low pressure in Paraguay, systems studied by Seluchi and Saulo (2012), favoring this flow during the year. The east and southeast wind directions appear as those are more frequent, after the northeast wind, in the city of Maringá, located in the west of Paraná (GALVANI et al., 1999).
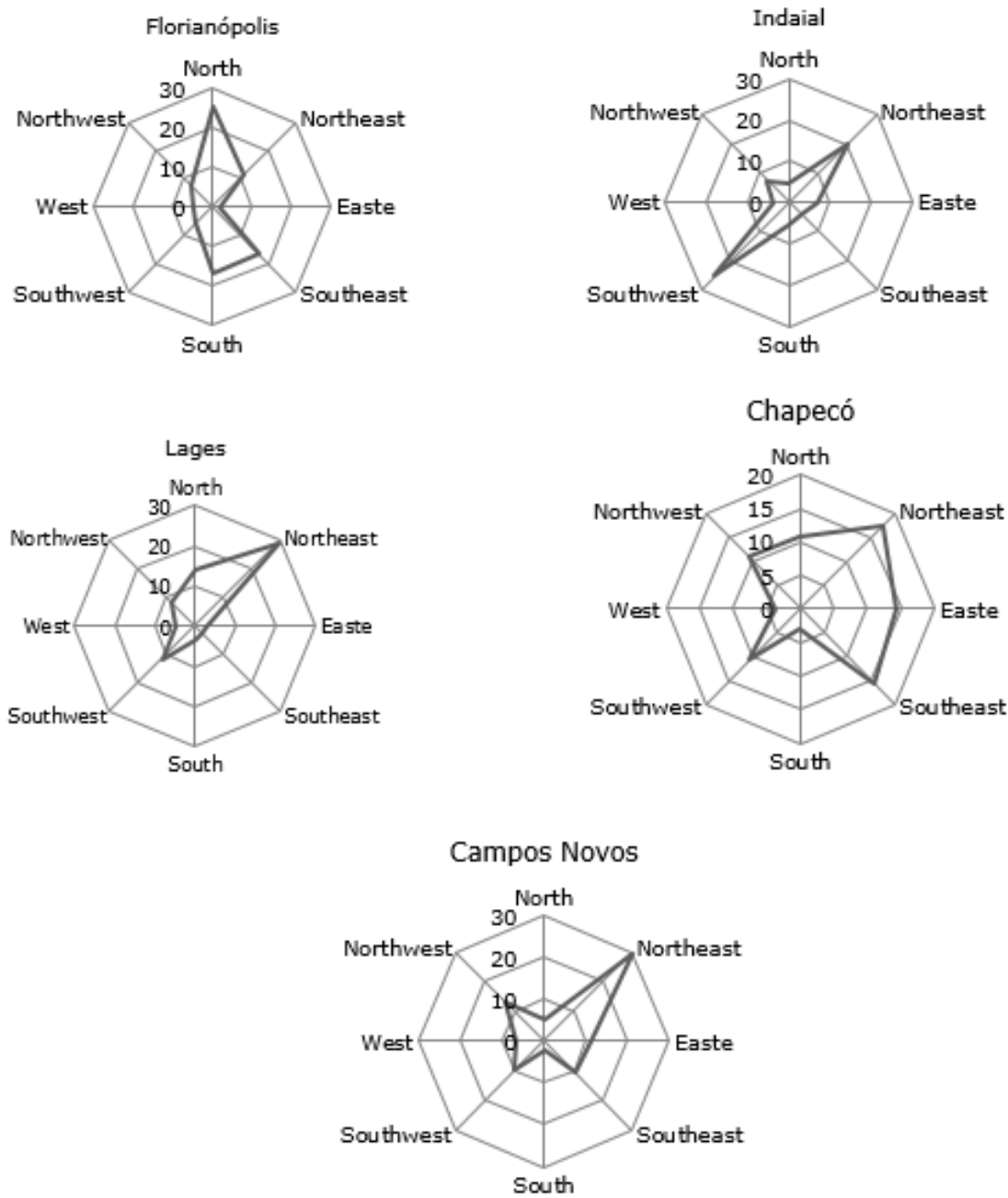

Figure 5 - Wind direction average frequency of the years from 1974 until 2016. 
The Figure 6 illustrate the wind direction main configuration in different weather stations, which can be understood from the circulation generated in association to the synoptic systems that act in the Santa Catarina state during the year, the South Atlantic subtropical anticyclone and troughs in the west of Santa Catarina, associated with low pressure in Paraguay.

The flux of northwest quadrant showed lower frequency in all the weather stations (Figure 5). It occurs hours before the cold frontal passage in Santa Catarina (RODRIGUES et al., 2004). The Chapecó and Campos Novos weather stations showed frequency in northwest direction too due to the cyclones (low pressure with wind clockwise) with center in Paraguay, which move towards the west of Santa Catarina.

Additionally, to the weather stations more distant to the coast of Santa Catarina, Chapecó, Campos Novos and Lages, it may be observed a wind amongst west and southwest (Figure 5). This wind is explained by the anticyclone trajectory (PEZZA, 2003), which invade south Brazil between April and October, bringing incursions of polar air after the cold front passage (Figure 7). In Pelotas, city located in the extreme south of Brazil, Silva et al. (1997) found a high frequency of southwest wind in the months of fall and winter. In southern latitudes, in La Plata, Argentina, where the migratory anticyclone incursions is higher (PEZZA, 2003), the wind frequency of southwest/south/southeast is so elevated as the frequency of northeast/north winds (RATTO and NICO, 2012).

The Florianópolis weather station showed the south and southeast directions with high frequency (Figure 5). In this region, the fall-winter anticyclones favors the south direction (Figure 7), while the spring-summer anticyclones favors the southeast wind (RODRIGUES et al., 2004). Similar results were obtained by Silveira et al. (2014), which analysis from 1996 until 2012 of the metropolitan region of Florianópolis presented south wind, that predominates in April and May, and southeast wind, that predominates in November and February.

Exclusively to Indaial, where the lowest wind velocities were registered, there was found a local wind influence in the average wind direction, of southwest predominance, due to its location in the Itajaí valley. According to Prudêncio (2002) and Prudêncio et al. (2017), in this region of valley, the local circulation undergoes a great influence of topography, which induces a mountain-valley circulation in nighttime, favoring northwest, west and southwest winds. In this period, the temperature contrast between the valley (warmer) and the mountain region favors a wind movement from the mountain towards the valley. To the city of Seropédica, in Rio de Janeiro, located between hillside areas of Serra do Mar and adjacent ocean, Oliveira Junior et al. (2013) found wind directions associated with sea breeze circulation, as well as valleymountain breeze. Even so, the municipality also presented a constant frequency of northeast winds, due to the action of the subtropical anticyclone of the South Atlantic. 


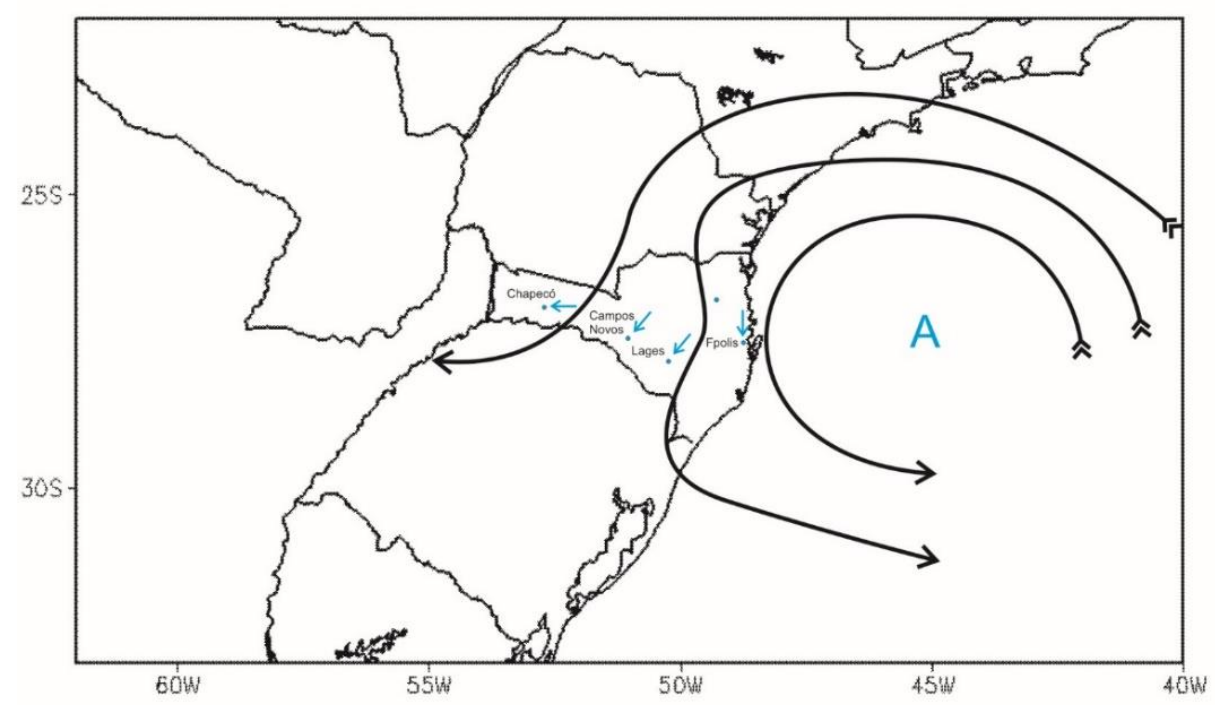

Figure 6 - Main wind direction in Santa Catarina weather stations (climatology 19742016) and the associated standard atmospheric circulation. Illustration: Fabricio Vidal.

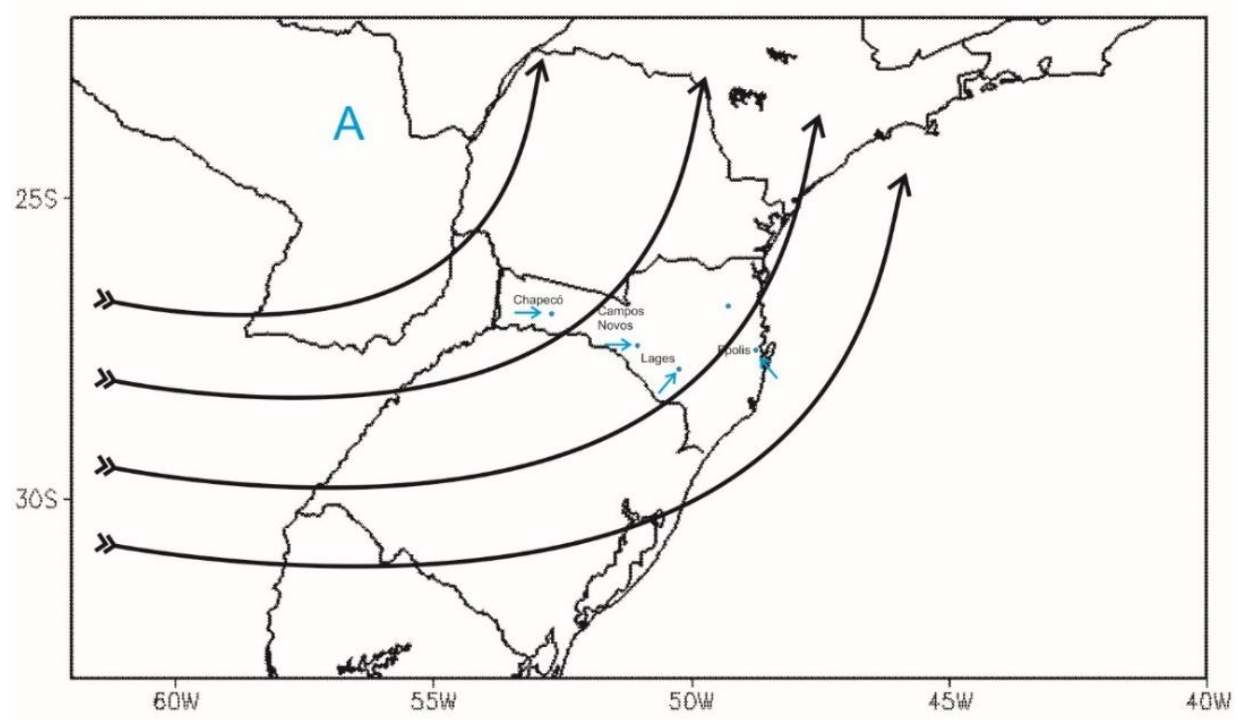

Figure 7 - Secondary wind direction in Santa Catarina weather stations (climatology 1974-2016) and the associated standard atmospheric circulation. Illustration: Fabricio Vidal.

The calm winds occurrences were plotted separated to the directions (Figure 8), once calm winds are not considered in the wind rose.

It is noticed that Indaial and Lages presented the highest frequencies of calm wind, representing more than $20 \%$ of its winds registers, while Chapecó and Campos Novos presented little more than $10 \%$ of calm winds registers and 
Florianópolis showed only $9,97 \%$. If related to the previous subsection of wind velocities, it may be observed that the weather stations that showed more calm wind registers are also those that showed the lowest wind velocities, whereas Florianópolis, that showed the smallest calm wind period, is also the one that showed the highest wind averages velocities.

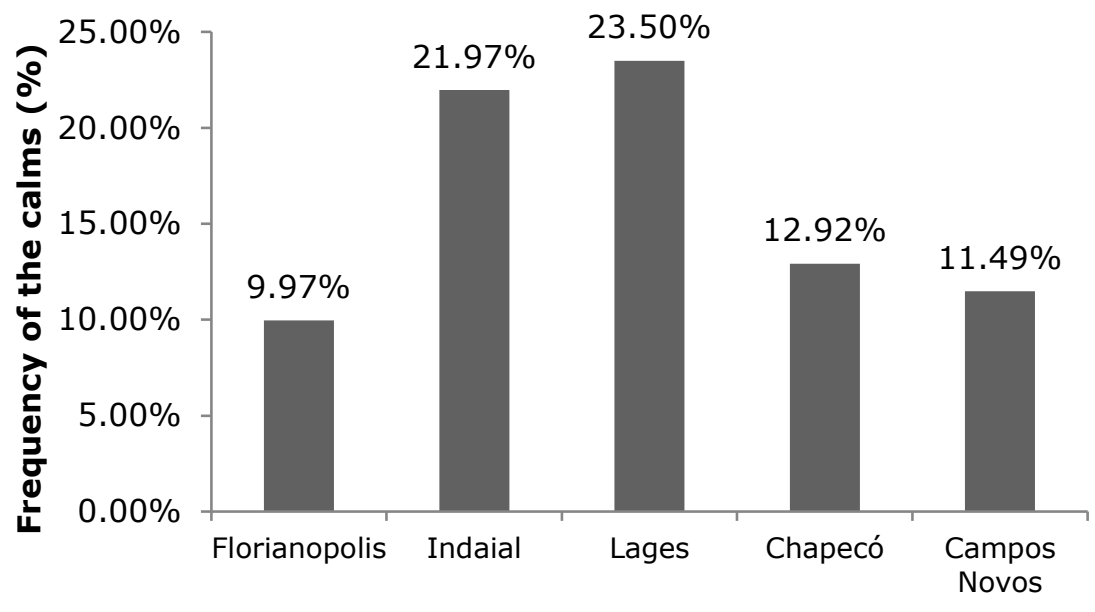

Weather stations

Figure 8 - Calm wind frequencies in the five weather stations from 1974 until 2016.

\section{CONCLUSIONS}

About the wind velocity, Florianópolis and Campos Novos registered the highest velocities during the year. This condition is expected to the weather station located in the coast (Florianópolis). In Campos Novos, the high wind speed in relation to Lages may be associated with less influence of the barriers in its proximities. The days with persistent high wind velocities registers are associated to the cold fronts influence (Chapecó, Campos Novos, Lages) and extratropical cyclones (Florianópolis, Indaial) that cause high-pressure gradients in the region and for extended period.

The predominance of South Atlantic subtropical anticyclone was observed most of the year, from the coastal areas to those away from the coast, with a predominant north circulation in Florianópolis, turning to northeast in Lages and Campos Novos. In these three locations, the wind velocity increases mainly during the spring months, due to the action of the west edge of the South Atlantic Subtropical Anticyclone, when its center moves away from the continent. The influence of low-pressure systems during the year, in the west of Santa Catarina (Chapecó), may be observed in the predominant east/southeast wind direction, and more constant wind velocity in most of the months. In four weather stations, the southwest and south wind direction is governed by the migratory anticyclones in the winter, which advance from Argentina to the state of Santa Catarina.

Whereas at all these stations the wind flow is generated in the dominant synoptic circulation (high and low-pressure systems), in the Itajaí valley 
weather station (Indaial), the mountain-valley breeze effect induces a predominant local circulation of southwest.

\section{REFERENCES}

ALVES, M. P. A.; VANZ, A.; CRUZ, G. S.; MARTARELLO, K. de C. B. K.; MONTEIRO, A. N.; MISZINSKI, J. Caracterização da Forte Onda de calor de 2014 em Santa Catarina. Ciência e Natura, v.38 n.1, p. 309 - 325, 2016.

AYOADE, J. O. Introdução à climatologia para os trópicos. São Paulo: DIFEL, 1996.

BENISTON, M.; STEPHENSON, D. B. Extreme climatic events and their evolution under changing climatic conditions. Global and planetary change, v. 44, p. 1-9, 2004.

BITENCOURT, D.P.; ACEVEDO, O.C.; GAN, M.A.; FUENTES, M.V.; MUZA, M.N.; RODRIGUES, M.L.; QUADRO, M.F.L.. Relating winds along the Southern Brazilian coast to extratropical cyclones. Meteorological Applications, v.18, n.2, p. 223 229, 2011.

BITENCOURT, D. P.; FUENTES, M. V.; CALEARO, D. S. Análise de variáveis atmosféricas observadas em alta resolução espaço-temporal durante um experimento de 30 dias na Mesorregião da Ilha de Santa Catarina. Revista Brasileira de Meteorologia, v.31, n.2, p. 122 - 140, 2016.

BITENCOURT, N. de L. da R.; ROCHA, I. de O. Percepção das Populações Costeiras sobre os Efeitos dos Eventos Adversos no Extremo Sul de Santa Catarina - Brasil. Revista de Gestão Costeira Integrada, v. 14, p.15-25, 2014.

CARDOSO, C. de S.; BITENCOURT, D. P.; MENDONÇA, M. Comportamento do vento no setor leste de Santa Catarina sob influência de ciclones extratropicais. Revista Brasileira de Meteorologia, v.27, n.1, p. 39 - 48, 2012.

CAVALCANTI, I. F. A.; KOUSKY, V. E. Parte I - Sistemas meteorológicos que afetam o tempo na América do Sul: Frentes frias sobre o Brasil. In: Tempo e Clima no Brasil. Cavalcanti, I. F. A., N. J. Ferreira, M. G. Justi da Silva, M. A. F. Silva Dias, Eds., Editora Oficina de Textos, São Paulo, p. 135-147, 2009.

DURADOÑA, V.; GUGGERI, A.; ORTELI, S. Avanços na caracterização dos eventos de vento forte no Uruguai. Ciência e Natura Ed. Especial- IX Workshop Brasileiro de Micrometeorologia, v.38, 129-136, 2015.

FeitosA, E. A. N.; PEREIRA, A. L.; VeledA, D.; SilvA, G.; CAHETÉ, C. Panorama do potencial eólico no brasil. Brasília, Dupligráfica, 2003.

GALVANI, E; KLOSOWSKI, E. S; CUNHA, A. R., MARTINS, D. Caracterização da direção predominante do vento em Maringá, PR. Revista Brasileira de Agrometereologia, Santa Maria, v. 7, n. 1, p. 81-90, 1999.

GAN, M. A.; RAO, V. B. Surface Cyclogenesis over South America. Monthly Weather Review, v. 119, n. 5, p. 1293-1302, 1991.

GONÇALVES, R. C. Análise de frequência regional de ventos extremos no Paraná. Dissertação (Mestrado). Programa de Pós-Graduação em Engenharia de Recursos Hídricos e Ambiental. Universidade Federal do Paraná. Curitiba, 2007. 
GRIMM, A. M. Clima da Região Sul do Brasil. In: Tempo e Clima no Brasil. Cavalcanti, I. F. A., N. J. Ferreira, M. G. Justi da Silva, M. A. F. Silva Dias, Eds., Editora Oficina de Textos, São Paulo, Capítulo 17, p. 259-275, 2009.

HASSAN, V. V. Características Meteorológicas do Ambiente Sinótico e de Meseoescala Associadas ao Evento de Tornado na Cidade de Xanxerê - SC, em Abril de 2015. Anuário do Instituto de Geociências - UFRJ. 40, p. 131- 138, 2017.

HERRMANN, M. L de P (org). Atlas de desastres naturais de Santa Catarina. Florianópolis: SEA/DEGED-Copy Laser Gráfica Digital, 2007.

IBGE. INSTITUTO BRASILEIRO DE GEOGRAFIA E ESTATÍSTICA. Santa Catarina: panorama. Available at: < https://cidades.ibge.gov.br/brasil/sc/panorama> Acessed on: 01 Sept. 2018.

INTERGOVERNAMENTAL PANEL ON CLIMATE CHANGE - IPCC. Climate change 2007. Geneva, Switzerland, 2007, 104 p.

LEITE, M. de L.; VIRGENS FILHO; J. S. Avaliação da velocidade média e direção predominante do vento em Ponta Grossa - PR. Revista Brasileira de Agrometeorologia, v. 14, n.2, p. 157-167, 2006.

LOPES, A. R. S.; ESPÍNDOLA, M. A. O Furacão Catarina: A transformação na percepção ambiental em Santa Catarina-Brasil. Available at: < http://www.encontro2012.historiaoral.org.br/resources/anais/3/1340200755_A RQUIVO_OFuracaoCatarina_final.pdf> Acesso em: 01. Sep. 2018

MARIM, F. R.; ASSAD, E. D.; PILAU, F. G. Clima e Ambiente: Introdução à climatologia para ciências ambientais. Campinas: EMBRAPA Informática Agropecuária, 2008. 127 p.

MUNHOZ, F. C.; GARCIA, A. Caracterização da velocidade e direção predominante dos ventos para a localidade de Ituverava-SP. Revista Brasileira de Meteorologia, v.23, n.1, p. 30-34, 2008.

NASCIMENTO, E. L.; DOSWELL III, C. A. The need for an improved documentation of severe thunderstorms and tornadoes in South America. In: Proc. Severe Local Storms Special Symposium, 86th AMS Annual Meeting, Atlanta, USA, paper P. 2006.

NETO, F. G. Eventos climáticos extremos na agricultura e tecnologia para redução de danos na olericultura em Santa Catarina. In: VIII Encontro de Economia Catarinense. Anais... Rio do Sul, 2014.

OLIVEIRA JUNIOR, J. F.; SOUZA, J. C. S.; DIAS, F. O.; GOIS, G.; GONÇALVES, I. F. S.; SOARES da SILVA, M. Caracterização do regime de vento no município de Seropédica, Rio de Janeiro (2001-2010). Floresta e Ambiente, Rio de Janeiro, v. 20 , n. 4 , p. 447-459, 2013.

PANDOLFO, C.; BRAGA, H. J.; SILVA JÚNIOR, V. D.; MASSIGNAM, A. M.; PEREIRA, E. S; , THOMÉ, U. M. R.; \& VALCI, F. V. A. Atlas climatológico do estado de Santa Catarina. Florianópolis: Epagri, v.1, 2002.

PEREIRA, N. Ciclones extratropicais e eventos extremos chuvosos sobre a bacia do Rio da Prata. 96 p. Dissertação (Mestrado em Meteorologia) - Universidade de São Paulo, São Paulo, 2013. 
PEZZA, A. B. Ondas de frio na América do Sul e as trajetórias dos ciclones e anticiclones extratropicais: Climatologia sinótica. Tese de Doutorado em Meteorologia, Universidade de São Paulo, São Paulo, 369 p., 2003.

PRUDÊNCIO, R. S. Estudo do sistema de circulação de brisas no litoral de Santa Catarina. Monografia de Especialização em Meteorologia, UFPel, 2002.

PRUDÊNCIO, R. S.; RODRIGUES, M. L. G.; NERY, T. J.; PISSI, E. Estudo da influência da circulação local em eventos de precipitação extrema no Vale do Itajaí (SC). In: XVII SIMPÓSIO BRASILEIRO DE GEOGRAFIA FÍSICA APLICADA. Anais ... Campinas, 2017.

RATTO, G.; NICO, A. Preliminary wind analysis regarding different speed ranges in the city of La Plata, Argentina. Revista Brasileira de Meteorologia, v.27, n.3, p. $281-290,2012$.

RODRIGUES, M. L. G.; CALEARO, D.; ARAUJO, G.; MORAES, M.; MONTEIRO, M.; CORREA, C.; MARTINS, M.; LIMA, M.; BRAGA, H. Catarina: O monitoramento do fenômeno pelos meteorologistas da Epagri/Ciram. Boletim da Sociedade Brasileira de Meteorologia, v.29, p. 11-16, 2005.

RODRIGUES, M. L. G.; FRANCO, D.; SUGAHARA S. Climatologia de frentes frias no litoral de Santa Catarina. Revista Brasileira de Geofísica, v.22, n.2, p.135$151,2004$.

RODRIGUES, T. S.; DE QUADRO, M. F. L.; FUENTES, M. V. Wind mapping of Federal Institute of Santa Catarina-campus Florianópolis. Ciência e Natura, v.38, n.1, 354, 2016.

SATYAMURTY, P.; NOBRE, C. A; SILVA DIAS, P. L. Tropics - South America. In: Meteorology of the Southern Hemisphere, Ed. Kauly, D. J. and Vincent, D. G., Meteorological Monograph. American Meteorological Society, Boston, p. 119-139 1998.

SELUCHI, M. E.; SAULO, A. C. Baixa do Noroeste Argentino e Baixa do Chaco: Características, diferenças e semelhanças. Revista Brasileira de Meteorologia, v.27, n.1, p.49-60, 2012.

SILVA, J. B.; ZANUSSO, J. T.; SILVEIRA, D. L. M.; SCHONS, R. L.; LARROZA, E. G. Estudo da velocidade e direção dos ventos em Pelotas, RS. Revista Brasileira de Agrometeorologia, Santa Maria, v. 5, n. 2, p. 227-235, 1997.

SILVA, R. L.; VIEIRA, M. M. Direção predominante, velocidade do vento e suas frequências de ocorrência em Dourados-MS. Revista Energia na Agricultura, Botucatu, v. 31, n. 4, p. 348-355, 2016.

SILVEIRA, R. B.; ALVES, M. P. A.; MURARA, P. Estudo de caracterização da direção predominante dos ventos no litoral de Santa Catarina. In: X SIMPÓSIO BRASILEIRO DE CLIMATOLOGIA GEOGRÁFICA. Anais ... Curitiba, p. 380-392, 2014.

WORLD METEOROLOGICAL ORGANIZATION - WMO. Manual on Codes: International Codes. v. 1. Part A - Alphanumeric Codes. Section D. No. 306: 2016.

ZIPSER, E. J., CECIL, D. J.; LIU, C.; NESBITT, S. W., YORTY, D. P. Where are the most intense thunderstorms on Earth? Bulletin of the American Meteorological Society, v. 87, n. 8, p. 1057-1071, 2006. 